\section{Confusion over European rules}

THE announcement this week of a new and supposedly safe vaccine against rabies (see pages 304 and 373) may bring to a head a simmering conflict in Europe over whether to permit the release of genetically engineered organisms.

The new vaccine is a version of the vaccinia virus, which is related to smallpox but much less dangerous, engineered to express a protein from the coat of the rabies virus, and thus create immunity in any creature inoculated with the vaccine. Target populations are foxes in Europe and raccoons on the east coast of the United States. Both, in principle, could be fed the vaccine in infected bait.

Developed by the French genetic engineering company Transgène in Strasbourg, the vaccine will be commercialized by Mérieux of Lyons, where chief scientist Philippe Desmettre said last week that there are no immediate plans for field trials. French regulations require approval of such trials by the ministries of health and agriculture, but Mérieux has not so far applied for permission. The company has supplied vaccine for tests by the Wistar Institute in Philadelphia, but use of the vaccine in the wild is likely to take place in Europe first, said Desmettre

In Europe, there is no general agreement on how to regulate field trials. Denmark has jumped the gun and already imposed controls; in West Germany and in the European Parliament, the Green release of genetically engineered organisms, but in Britain, France, the Netherlands and elsewhere there seems little concern. In the midst of this confusion, the European Commission is attempting to create a little order rather than see yet another European market divided by multifarious regulations. But the Commission itself is a house divided, with those representing scientific, industrial and agricultural interests in conflict with the environment directorate.

Nevertheless, Commission officials said last week that a paper on the problem is now circulating and is likely to be presented to the European Council of Ministers towards the end of this month. This, however, would merely alert ministers that there is an issue to be discussed and it is not even clear at what council the issue would be thrashed out. The European Parliament, whose irritant value - if not real power - is steadily increasing in the European pantheon, will debate a hardhitting report on the same issues by Dutch socialist Phili Viehoff, later this year. Not only will Viehoff present her report, but six other committees covering biotechnology and the environment will also table positions, leading to what could be an acrimonious debate.

The Commission itself is aiming to sub- mit joint safety proposals to Council by April next year - Denmark's "banning" of the release of engineered organisms, hailed as a success by Europe's greens, is not a major obstacle, for trials are not truly "banned" although they must be referred to the government for approval.

In the next few weeks, a major report should appear by the Organisation for Economic Cooperation and Development (OECD) in Paris on "safety considerations in the use of recombinant DNA". It is said by those who have seen it to be a "very reassuring report", arguing that risks are small. Britain is expected to base its own guidelines on the OECD recommendations.

Robert Walgate

\section{Chinese science}

\section{Back to your work units}

CHINA is to introduce new rules on foreign study. Although the number of people sent abroad to study at government expense is to remain at its present level, the mix will be different. There will be more emphasis on those applied disciplines necessary for China's modernization programme, and less opportunity for students to go abroad immediately after completing their first degrees. On the other hand, the number of people with masters' degrees who go abroad to work for a doctorate will be increased. Students who go abroad at their own expense (mainly the children of top officials, plus the lucky few who have wealthy relatives abroad) will be given greater "guidance" to ensure that their chosen studies also conform with the state plan.

The changes are meant to ensure a sufficient supply of trained personnel to satisfy the demands of "work units" throughout the country. "Poaching" of graduates from their assigned jobs is now a problem in China. Understaffed enterprises frequently offer substantial and fringe benefits to well-trained recruits; they even advertise in newsletters which flourish in spite of official disapproval. The new rules should frustrate the "poachers". From this year onward, most of the quotas for government-sponsored students will be assigned to enterprises and work units in need of trained staff; the latter will then select who is to go abroad.

Foreign study, it is stressed, is not meant to be simply a means of self-betterment. Those who obtain a doctoral degree abroad will not now be permitted to stay on just to acquire a still higher qualification. Instead, they will have to return to an appropriate job in China for several years, before being sent abroad again. This, it is explained, will better help them coordinate their studies with China's needs.

Vera Rich 